BERUMPUIN

International Journal of Social, Politics, and Humanities

https://berumpun.ubb.ac.id/index.php/BRP

\title{
TOURISM VERSUS MINING: CONTESTED SPACE IN TANJUNG PUTAT BEACH AND LEPAR BEACH, BELINYU DISTRICT, BANGKA REGENCY
}

\author{
Berlian Zarina ${ }^{1}$, Ibrahim², Rini Arcdha Saputri ${ }^{3}$, Rendy 4 \\ 1,2,3,4 Department of Political Science, Faculty of Social and Political Sciences, Universitas \\ Bangka Belitung, Indonesia
}

\begin{tabular}{l}
\hline ARTICLE INFO \\
\hline Received: 07-08-2021 \\
Accepted: $24-10-2021$ \\
Published: $30-10-2021$ \\
Volume: 4 \\
Issue: 2 \\
DOI: \\
https://doi.org/10.33019/berumpun.v3i1.62 \\
\hline KEYWORDS
\end{tabular}

Tourism, spatial mining, Tanjung Putat

beach, Bangka Regency, Henry Lefebvre

\section{ABSTRACT}

\begin{abstract}
Tourism is one of the sustainable income sectors that is predicted as a post-mining sector. Thus, the area of tourism activities, especially beaches are minimized to be damaged, including juxtaposing it with mining. The research aims to elaborate on spatial contestation that occurred at Tanjung Putat Beach and Lepar Beach, Belinyu District, Bangka Regency. The theoretical basis used in this research is using the concept of spatial production from Henri Lefebvre which consists of 3 concepts related to the production of space, namely spatial practice, representational space, and spatial representation. The method of the research is qualitative with a descriptive method. In collecting the data, in-depth interviews were used with the informants who were closely related to the research being studied. The spatial contestation has indeed occurred in Tanjung Putat Beach and Lepar Beach, Belinyu District, Bangka Regency. However, the impact of mining activities has an impact on tourism in the vicinity, this is reinforced by protests against these mining activities.
\end{abstract}

\section{INTRODUCTION}

Mining activities started in Bangka in 1711, in Singkep in 1812, and in Belitung in 1852. Tin mining activities in Bangka Belitung and Singkep have been going on since the Dutch colonial era until now (Swastiwi et al, 2017). In the mining sector, tin is still the main source of income for the regional government of the Bangka Belitung Islands Province, but until 2014 the mining sector was no longer the main source of income for the Gross Regional Domestic Product (GDP) of Bangka Belitung (Wardhani and Valeriani, 2016).

The tourism sector in Bangka Belitung is well known for its beautiful sea, beaches and clusters of islands. Tourism itself is one sector that has been proven to be a sector that plays a role in national development in Indonesia. Tourism can also compete with the oil and gas sector as one of the largest foreign exchange earners in Indonesia (Sumargana in Cipta, 2017). In 2019, Bangka Belitung Provincial Government also managed to reap GDP of Rp 
63.5 billion from the tourism sector. This is due to the increase in the number of tourist visits which continue to increase by around $9 \%$ every year (Ferdiansyah, 2020).

This mess of tin in Bangka Belitung started around the 2000s and above after the national tin deregulation. Furthermore, this has been going on in the last 20 years (Erwiza, 2010; Ibrahim, et all, 2020; Sujadmi and Murtasidin, 2020). Changes in the landscape of Bangka are increasingly visible with tin mining that is rampant, uncontrolled, only concerned with profit in which focus on state-led economic development and does not carry out reclamation to improve post-mining land and to control the environmental damage. Mining land has also to shifted to historical places, residential areas, agricultural and plantation lands, protected forests, green lines, to coastal tourist areas which are certainly related to marine (Erman, 2010 ; Rendy, 2017 ; Rendy, 2019). Several sectors that can be several alternatives for tin mining are agriculture, fisheries and forestry, as well as trade, hotels, and restaurants in which the tourism sector is included. Moreover, tourism could be designed for post tin mining economy, and to accelerate the transition of local socioeconomics transformation from extractivism to tourism (Ibrahim, et all, 2020). Those could also be followed by ecological commitments by all stakeholders (Ibrahim, et all, 2019 ; Rendy, et all, 2020 ; Wardhani and Valeriani, 2016).

At first, tin mining was only carried out on land in the Bangka Belitung region. However, as time goes by, it is difficult to find mining locations rich in tin on land, resulting in lower yields of onshore mining and the high operational costs incurred, making the community and tin mining companies switch locations to marine mining (Mildan in Ibrahim, 2015).

Table 1. Income through Mining and Tourism

\begin{tabular}{lcccrc}
\hline Tahun & $\begin{array}{c}\text { Sektor } \\
\text { pertambangan } \\
(\mathbf{R p})\end{array}$ & $\begin{array}{c}\text { Sektor } \\
\text { Pariwiwsata } \\
(\mathbf{R p})\end{array}$ & $\begin{array}{c}\text { Total PAD } \\
(\mathbf{R p})\end{array}$ & $\begin{array}{c}\text { Sektor } \\
\text { Pertambangan } \\
(\%)\end{array}$ & $\begin{array}{c}\text { Sektor } \\
\text { pariwiwsata } \\
(\%)\end{array}$ \\
\hline 2014 & 59.591 .345 .847 & 31.742 .903 .149 & 427.580 .506 .879 & 13,94 & 7,42 \\
2015 & 35.230 .805 .563 & 35.576 .078 .187 & 599.620 .953 .180 & 5,93 & 5,92 \\
2016 & 72.771 .417 .844 & 47.957 .942 .361 & 663.445 .639 .676 & 10,97 & 7,23 \\
2017 & 96.237 .290 .589 & 49.857 .480 .706 & 879.784 .561 .698 & 10,94 & 5,67 \\
2018 & 114.215 .783 .026 & 57.595 .728 .153 & 848.330 .012 .018 & 13,46 & 6,79 \\
\hline
\end{tabular}

Sumber: Badan Keuangan Daerah Prov. Kep.Bangka Belitung, diolah peneliti (2019)

Source: Data processed by Nesti Varicela in Thesis entitled "Comparison of the Role of Regional Original Income in the Mining Sector and the Tourism Sector in Improving the Economy of Bangka Belitung Province

Based on the data above, we can see that the mining sector is still the leading sector. However, income from the tourism sector also continues to increase from year to year. Thus, tourism areas that have economic potential must be treated and to a minimum decrease the 
damage of area, in order to continue to provide good economic input in the future. If mining in the sea and coastal areas continues, one of the regional incomes, namely the tourism sector, will only be a memory.

The legal conception regulated in Law Number 26 of 2007 concerning Spatial Planning as regulated in Article 1, where space is a container that includes land space, sea space, and air space, including space within the earth as a unitary area, where humans and Living things carry out activities and carry out their survival. The space itself has interactive characteristics, both from investors or entrepreneurs, the government, and the community who have concern for their area including their concern for the surrounding environment. Therefore, conflicts and contestations between actors in spatial practice cannot be avoided (Aminah, 2015). Citing the idea of Lefebvre in Aminah (2015) which says that space is a political product and a tool for socio-economic change, so that space tends not to be neutral and passive. This is also one of the factors that make the use of space from time to time continue to change.

This study uses Henri Lefebvre's theory, namely the production of space, which includes spatial practices related to the use of space in accordance with existing regulations, spatial representation related to the government's role as a liaison between the community and interested parties in space, as well as representational space related to the sustainability of space that in the future. This theory is very relevant to the research conducted, in addition to discussing the use of space, this theory also relates the development of modernism and capitalism which also now has a close relationship with the use of space, especially in this case tourism and mining space which are both leading sectors in Bangka Belitung.

Various studies related to spatial planning have previously been carried out, such as the research conducted by Sujadmi and Bahjatul Murtasidin in 2020 entitled «Sea Spatial Planning: Conflict, Negotiation, and Contest of Interests of Local Political Economy in Bangka Belitung», but this research covers Bangka Belitung in general as well as discussing marine space as a contestation arena. In addition, the thesis written by Riska Agustis in 2017 with the title «Common Pool Resources Conflict Management amidst Diversity of Interests: Case Study of Kelabat Bay and Matras Sea, Bangka Regency», in this thesis stems from a conflict between traditional fishing communities and PT. Tin is fighting over access to the Teluk Kelabat and Matras Sea as shared resources. Where in this study more emphasis on conflict mechanisms and conflict strategies. So that the research carried out related to spatial contestation is still minimal, especially those related to tourism and mining in adjacent spaces.

Coastal tourism and mining will certainly have an impact, especially for coastal tourism itself. Something similar to the explanation above is what happened in one area in the north of Bangka Island. Where the shift in space that occurs in society. The tourism areas, 
namely Tanjung Putat Beach and Lepar Beach, which are famous for their flowing water in Belinyu District and are so close to tourists, are now starting to be threatened by the presence of marine mines around the coastal area. Previously this beach tourism area was a tourist that was commonly visited by the public, whether it was just enjoying the beach atmosphere, swimming, relaxing, or while enjoying various snacks around the beach.

The presence of tin mines around the coast is not only spoils the sight of tourists who enjoy the beauty of the beach, but also adds to the damage to the beach which results in the activities of tourists who usually swim in the tourist area. According to Yustiani, Rusmaya, and Pratama (2012), where the dredging process is by dredging the seabed which only contains lead, the separation between mining waste which includes clay, mud, tailings, stones, and sand is discharged directly into the sea without any processing first. In addition the sea water becomes cloudy and expands because it is carried away by ocean waves.

Based on information obtained from the Head of Tourism Awareness Community Belinyu, it currently there are about 4 suction boats perched around Tanjung Putat Beach. Meanwhile, according to information obtained from the Chairman of the Greenboys, where there is a marine mine known as the production suction pontoon (PIP) located around the Lepar beach. The marine mining around the coast is accompanied by the improvement of the tourist area which is so intensive which then creates a spatial contestation in the Tanjung Putat Beach and Lepar Beach areas.

According to information obtained from the Head of Tourism Awareness Community Belinyu and Chair of Greenboys as tourism activists, there are several impacts caused by the existence of marine mining. Starting from the decline in the number of tourists which led to the income of the tourist area, the sea water was starting to turn cloudy, and it also had an impact on the surrounding community who work as fishermen who participated in experiencing a decrease in catch income. Nature-based tourism space as a place for people to carry out recreational activities as well as a place for some people to continue for carrying out their lives, both earning a living as traders around tourism sites, as fishermen looking for the results of existing marine resources, as well as earth-producing other professions others in the area. In addition, tourism, one of which is the beach, which is predicted as a sustainable sector to replace the mining sector, is now threatened by the presence of mining in marine areas. At Tanjung Putat Beach and Lepar Beach, Belinyu District, the distance from marine mining carried out by the Production Suction Pontoon is not far from the shoreline and has an impact on the surrounding coastal tourism area and parties related to coastal tourism. The explanation above is what makes researchers interested in discussing further related to tourism and mining. Where the spatial layout that has been determined creates a contestation between adjacent and interconnected spaces. 


\section{METHODOLOGY}

The research method used in this research is using descriptive qualitative method. The main focus of this study is the spatial contestation between tourism and mining, one of which is Tanjung Putat Beach and Lepar Beach, Belinyu District, Bangka Regency. The data collection technique used in this research is to conduct in-depth and unstructured interviews with purposive sampling technique as the determination of informants. Purposive sampling was used because of certain considerations for the informants before being used as informants. Such as resource persons who are closely related to tourism and mining institutions, as well as individual or institutional sources that are related and relevant to the object of research. There were 11 informants who were interviewed in this study. 2 of them are managers of tourist areas as research objects, while the other 9 are people who are in institutions such as urban villages, sub-districts, districts, and provinces. In addition, there are direct observations related to the location that is the object of research. This is use to get the growt and information about direct research location.

\section{DISCUSSION}

\section{A. The Turmoil of Marine Mines that Go Along with Tourist Areas}

The fame of Bangka Belitung until now cannot be separated from its tin mining and exotic tourism. These two sectors are the leading sectors on the island with the nickname tin island. The tourism sector is one of the focuses of development carried out by the government. It can be seen from the inclusion of the tourism sector as one of the leading sectors in the regional medium-term development plan (RPJMD) to the regional long-term development plan (RPJPD) document. Bangka Belitung's macroeconomic dependence is quite large on tin mining, so the local government plans to be able to replace the role of mining with other sustainable sectors (Megawandi, 2020). Tourism is predicted as an example of a sustainable sector that is expected to provide the main income for the region.

The role of tin mining in regional income in 2017 was $10.59 \%$. In terms of numbers, it is not too big compared to the industrial sector, which is around $20.63 \%$. However, most of the downstream industry comes from mining (Megawandi, 2020). So that the role of tin mining itself is still very large in contributing to regional income.

Along with the increase in population, the consumption of space is increasingly diverse and increase, lands for mining activities on the mainland are increasingly difficult to obtain. It also relates to modernism and capitalism as previously described by Henri Lefebvre. In fact space is now adjusting to the times and its ownership is mostly controlled by people, especially the upper middle classes. In addition, the relatively high cost of onshore mining operations causes mining to also penetrate the 
marine sector which is closely related to the typical tourism of Bangka Belitung which is famous for its sea and beaches. Thus, carrying out mining activities around the coastal tourism area will greatly impact the coastal tourism area in the future. The same thing happened in the tourist areas of Tanjung Putat Beach and Lepar Beach, Belinyu District, Bangka Regency.

Table 2. Data on Community Employment in Belinyu District in 2018

\begin{tabular}{lc}
\hline \multicolumn{1}{c}{ Jenis Usaha } & Jumlah \\
\hline Petani & 9.973 \\
Industri & 566 \\
Konstruksi & 900 \\
Pedagang & 2.051 \\
Transportasi & 290 \\
PNS & 354 \\
TNI & 140 \\
Pensiunan PNS/TNI & 107 \\
Buruh Bangunan & 5.300 \\
Peternak Sapi & 6 \\
Peternak Itik & 120 \\
Nelayan & 1.250 \\
Penjahit & 50 \\
Pertambangan & 13.700 \\
\hline Source: Belinyu Districtin 2019 Figures
\end{tabular}

Based on the data from the Belinyu District in the 2019 figures above, it shows that work in the mining sector is the dominant occupation of the others. So that mining can become an influential sector for other sectors, including fisheries, agriculture, to tourism.

Marine mines tend to damage can be counter to coastal tourism itself. Then the impact caused and the resistance carried out is a contestation related to spatial planning within the scope of the area. In the contestation, the completion will determine how the sustainability of the space in the future.

In mid-2020, Tanjung Putat Beach and Lepar Beach, which are known to have one coastline and are located next to each other, were presented with a view of the Production Suction Ship (KIP) and Production Suction Pontoon (PIP) which were in 
BERUIMPUIN

International Journal of Social, Politics, and Humanities

https://berumpun.ubb.ac.id/index.php/BRP

production not far from the shoreline. This of course has an impact on tourism areas in the future because of these mining activities.

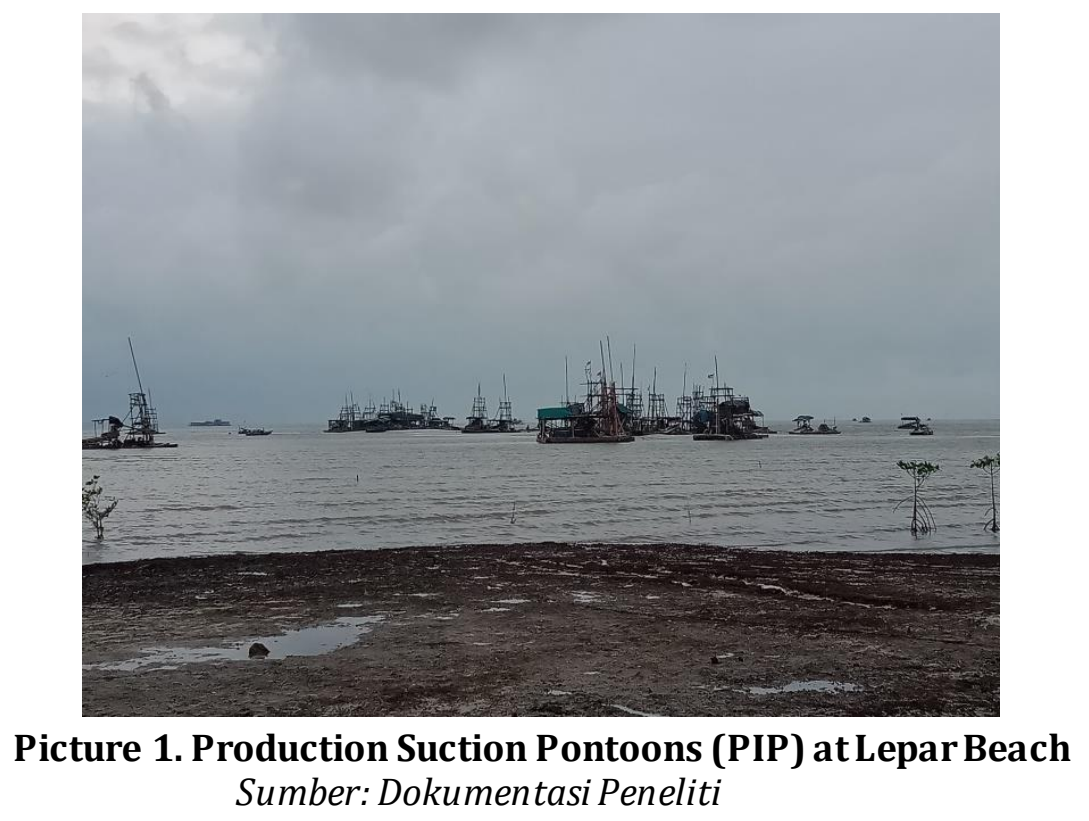

Based on the interview with the Managers of the Tanjung Putat Beach and Lepar Beach Tourism Areas, there are many impacts of marine mining on coastal tourism itself. Starting from the impact on tourists, traders around tourist areas, to fishermen who are not confirmed to have felt the impact. For the impact on the sea, Syarli as the Belinyu sub-district head also acknowledged the impact caused by the marine mining activity. As the head of the organization that manages the tourism area, Tourism

Awareness Community also received criticism from the community regarding the impact of marine mining on local tourism. On the other hand, Lepar Beach, which also has a coastline with Tanjung Putat Beach, has also experienced the impact of marine mining. Moreover, the existence of this production suction pontoon is not far from the lips of Lepar Beach itself.

Communities who members of Tourism Awareness Community and Grennboys as well as people who care about or are against the mining activities that occurred had protested in front of the PT. Timah, Belinyu District. They also had time to report to the security forces, such as the Navy, Airut, the village, sub-district, to the district level, to the provincial level. However, in this protest there was no meaningful response from the district and provincial parties. This is also due to problems that have been resolved at the sub-district level. 


\section{B. Legal Policy Utilization of Space}

In terms of spatial planning, the PUPR Service itself said that the Tanjung Putat Beach area is an industrial area, while the Lepar Beach area is a Protected Forest area. However, he explained that there is no problem if there are various activities in one space, because they also have rules for licensing in a space. In the Regional Spatial Planning regulations, both the Regency and the Province only regulate the land area. Meanwhile, what happened on Tanjung Putat Beach and Lepar Beach occurred in the sea area and regulations that were used as a reference in the spatial planning, namely the Regional Regulation of the Bangka Belitung Islands Province Number 3 of 2020 concerning the Zoning Plan for Coastal Areas and Small Islands (RZWP3K) Province of the Bangka Belitung Islands Year 2020-2040. Where there are mining activities that have an impact on surrounding tourism activities.

According to established regulations, Lepar Beach is a protected forest area which is then managed into tourism. This was stipulated through the Decree of the Ministry of Environment and Forestry No: SK.6510/MENLHKPSKL/PKPS/PSL.0/10/2018 on October 2, 2018. As for Tanjung Putat Beach itself, the Tourism Awareness Community has tried to get a letter related to tourism on the beach, but due to the pandemic constraints and the minimal budget from the Tourism Awareness Community itself, the permit letter is still hampered. However, in terms of spatial planning from the Department of Public Works and Spatial Planning, Bangka Regency itself, the Tanjung Putat Beach area is an industrial area. The management of Tanjung Putat Beach itself is carried out by the Serumpun Anchored Tourism Awareness Community, where this Tourism Awareness Community was also recently formed, namely in 2020. So there are still many things that need to be prepared to establish the official Tanjung Putat Beach as a tourism area.

The statement from Syarli as the sub-district head of Belinyu District also strengthens the statement that indeed the mining activities carried out have an impact on the tourist area. Moreover, the two tourist areas are both currently developing and gaining popularity among the public. He also explained that what was clear was related to the tourism area in Belinyu, namely the Penyusuk Beach.

Apart from the PUPR office, which explained that it doesn't matter if there are various activities in one space, even though they focus more on the land area. The Department of Marine Affairs and Fisheries of the Bangka Belitung Islands Province also explained related to zoning in the marine space area which has now used the RZWP3K regulation as a reference. The following is a map related to zoning around Tanjung Putat Beach and Lepar Beach, Belinyu District: 


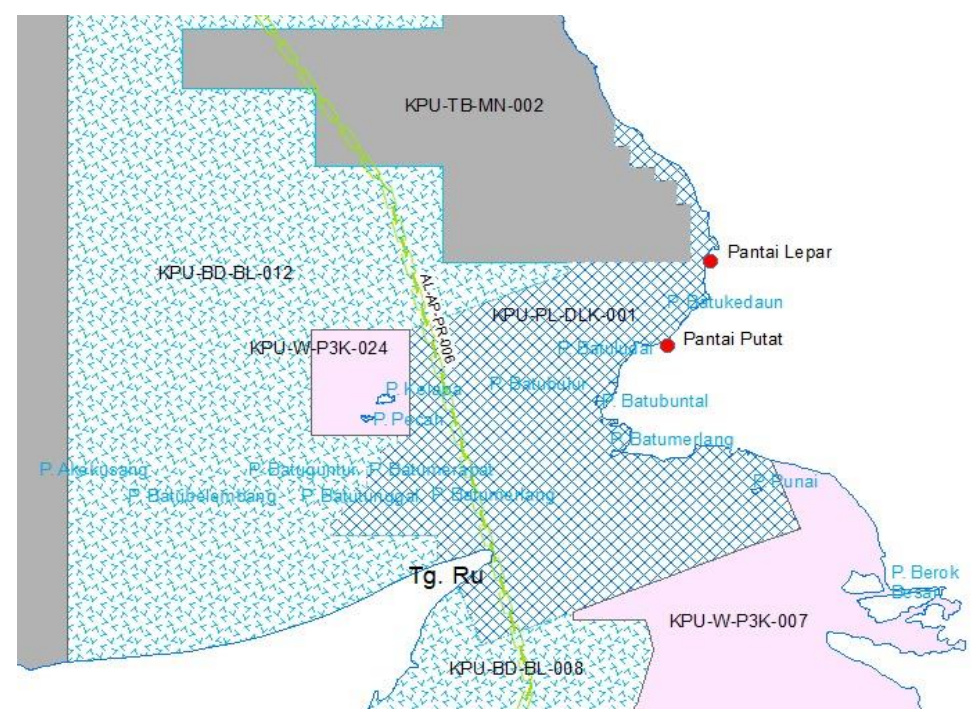

Picture 2. Zoning Map Related to Mining at Tanjung Putat Beach and Lepar Beach, Belinyu

District

Source: Department of Marine Affairs and Fisheries of the Bangka Belitung Islands Province

The Department of Marine Affairs and Fisheries of the Bangka Belitung Islands Province also explained that there are several zones in marine spatial planning ranging from 0-12 miles from the coast as stated in the RZWP3K regulation, namely there are capture fisheries zones, mining zones, tourism zones, cultivation zones, port zone, to industrial zone. The mining zone from Lepar Beach itself is about $250 \mathrm{~m}$ from the shoreline and from Tanjung Putat Beach is about $800 \mathrm{~m}$. With the regulation they do a clear permit related to mining activities, namely PT. Timah is working with its partners and they also carry out mining activities in mining zones.

The above explanation clearly explains that the mining activities carried out are legal and tourism utilization activities from Lepar Beach itself also have a clear legal basis regarding their tourism permits. Although the use of tourism is carried out only on the land area, and the use of tourism on Tanjung Putat Beach does not yet have a legal regulation on the use of space. However, the spatial layout here also proves that there is a spatial contestation between tourism and mining at Tanjung Putat Beach and Lepar Beach, Belinyu District, especially Lepar Beach which already has tourism utilization regulations. The contestation happens is because the mining activities carried out have an impact on the tourist area around the mining site. The impact in this case is cloudy water which results in people swimming on the beach, a decrease 
in the number of tourists which results in a decrease in the amount of income because the scenery on the beach is no longer pleasing to the eye which is accompanied by the presence of Production Suction Pontoons and annoying pontoon smoke. The theory previously described regarding space as a political product is also evidenced by the existence of the RZWP3K regulation that regulates mining zoning in this regulation, which previously, namely Law Number 1 of 2014 concerning Management of Coastal Areas and Small Islands, did not regulate mining zoning.

\section{CONCLUSION}

From the presentation that has been conveyed previously, there is indeed a spatial contestation between tourism and mining that has taken place at Tanjung Putat Beach and Lepar Beach, especially Lepar Beach which is clear in the legal rules for the use of space as a tourism area. The existence of this contestation is reinforced by the impact of marine mining activities which have an impact on the surrounding tourist areas. Marine mining in the tourist area has an impact on the decrease in the number of visitors which has an impact on the decrease in the amount of income for tourist areas, especially Lepar Beach, which has clear tourism utilization rules. In addition, the cloudy sea water due to marine mining makes tourists who come to swim feel disturbed, and the beach view has broken because of the offshore mining activities. From this detrimental impact, it has risen to political protests by the surrounding tourism communities, fishing communities, and some local non-governmental organizations. Those protests were carried out to villages, sub-districts, to provinces. However, there was no response from the district or provincial parties, this was because they had already obtained a settlement at the sub-district level.

The two activities that are running, be it tourism or mining, have clear rules. However, mining activities that tend to be destructive when juxtaposed with tourism activities that actually preserve the environment, this greatly impacts the tourism space in the future, plus tourism is predicted to be a sustainable post-mining income sector.

Henri Lefebvre's theory also supports that the development of a space is closely related to the development of modernism. In the mining case, tin is the leading sector in Bangka Belitung itself. So that it is difficult to let go, even though it goes hand in hand with tourism, especially beaches, which are predicted to be a sustainable regional income income sector after mining. This is also inseparable from the role of politics as a means of producing regulations related to licensing, so that an activity can be carried out and debated in one space. 


\section{REFERENCES}

Anastasia Wiwik Swastiwi et al. (2017). Lintas Sejarah Perdagangan Timah di BangkaBelitung Abad 19-20. Kepulauan Riau: Balai Pelestarian Nilai Budaya Kepulauan Riau.

Erwiza Erman. (2010). Aktor, Akses, dan Politik Lingkungan di Pertambangan Timah Bangka. Lembaga Ilmu Pengetahuan Indonesia. Edisi XXXVI/No. 2

Hendra Cipta. (2017). Kawasan Ekonomi Khusus dan Potensi Pariwisata Provinsi Kepulauan Bangka Belitung. Tawshiyah Vol. 12 No. 1

Ibrahim, et all. (2019). Between Tourism and Ecology: Review of Political Policy Commitments on Ecotourism Developmentin Bangka Belitung. E3S Web of Conferences 118. 04008

Ibrahim, et all. (2020). Dari Ekonomi ke Ekonomi Politik : Transformasi Setengah Hati Sektor Ekowisata di Bangka Belitung. Jurnal Wacana Politik. Vol. 5 No. 2 174-184

Ibrahim, et all. (2020). Ecotourism Development In Bangka Islands: An Exploratory Study Onparticipation and Expectations of Local Stakeholders. Journal of Physics : Comference Series. Vol. 1655

Indra Ibrahim. (2015). Dampak Penambangan Timah Illegal yang Merusak Ekosistem di Bangka Belitung. Selisik, Vol. 1, No. 1

Henri Lefebvre. (1991). The Production of Space. Donald Nicholson-Smith (Trans.). Victoria: Blackwell.

Nesda Varicela. (2019). Perbandingan Peran Pendapatan Asli Daerah Sektor Pertambangan Dan Sektor Pariwisata Dalam Meningkatkan Perekonomian Provinsi Kepulauan Bangka Belitung. Universitas Bangka Belitung.

Siti Aminah. (2015). Konflik dan Kontestasi Penataan Ruang Kota Surabaya. Masyarakat Vol 20, No. $159-79$

Sujadmi \& Bahjatul M. (2020). Perencanaan Tata Ruang Laut: Konflik, Negosiasi, dan Kontestasi Kepentingan Ekonomi Politik Lokal di Bangka Belitung. Jurnal Ilmiah Ilmu Pemerintahan. Vol. 5 No. 2.

Rendy. (2017). Menuntaskan Konsensus Lokal-Nasional (Yang) Berkelanjutan : (Membaca Ulang Rasionalisasi dan Idealisasi Pembangunan Model GBHN). Jurnal Society. Vol. 5 2331 
Rendy, et all. (2019). Ecological Political Commitments: Measuring The Ecological Leadership Vision of District Head in Bangka Belitung Region. Advances in Social Science, Education and Humanities Research. Vol. 389

Rendy Ferdiansyah. (2020). PAD Sektor Pariwisata Babel $R p \quad 63,5$ Miliar. (https://m.mediaindonesia.com/nusantara/293304/pad-sektor-pariwisata-babelrp635-milia) diakses pada 21 September 2021

Riska Agustis. (2017). Pengelolaan Konflik Common Pool Resources ditengah Keberagaman Kepentingan: Studi Kasus Teluk Kelabat dan Laut Matras, Kebupaten Bangka. Universitas Gadjah Mada.

Rulyanti Susi Wardhani \& Devi Valeriani. (2016). Green Tourism dalam Pengembangan Pariwisata di Bangka Belitung. Prosiding Seminar Nasional INDOCOMPAC Universitas Bakrie Jakarta, 2-3 Mei 2016.

Rusmaya Yustiani \& Pratama. (2012). Pengaruh Aktivitas Pertambangan Timah oleh Kapal Keruk Terhadap Kualitas Parameter Fisik (Kekeruhan, TSS, Suhu) Air Laut di Teluk Kelabat Belinyu Kabupaten Bangka. Vol 14, No. 2

Yan Megawandi. (2020). Pembagunan Pariwisata di Provinsi Kepulauan Bangka Belitung dalam Pendekatan Whole of Government. Jurnal Widyaiswara Indonesia. Vol. 1 No. 2

Peraturan Daerah Provinsi Kepulauan Bangka Belitung Nomor 3 Tahun 2020 Tentang Rencana Zonasi Wilayah Pesisir dan Pulau-Pulau Kecil Provinsi Kepulauan Bangka Belitung Tahun 2020-2040 